\title{
Aplikasi Spatio-Temporal Pembelajaran Biografi Para Ulama Bermazhab Syafi'i berbasis Mobile
}

\author{
${ }^{1}$ Wifda Muna Fatihia*, ${ }^{2}$ Ira Prasetyaningrum, ${ }^{3}$ Rengga Asmara, ${ }^{4}$ Kholid Fathoni \\ ${ }^{1,2,3}$ Departemen Teknik Informatika dan Komputer, Politeknik Elektronika Negeri Surabaya \\ ${ }^{4}$ Departemen Teknologi Multimedia Kreatif, Politeknik Elektronika Negeri Surabaya \\ Kampus, Jl. Raya ITS, Keputih, Kec. Sukolilo, Kota SBY, Jawa Timur 60111 \\ *e-mail: wifdamu@gmail.com
}

(received: 16 Juli 2021, revised: 11 September 2021, accepted: 16 September 2021)

\begin{abstract}
Abstrak
Sebagian besar muslim di dunia menganut Mazhab Syafi'i, sehingga pengetahuan mengenai Mazhab Syafi'i, utamanya biografi dan sanad keilmuan Imam Syafi'i dan para ulama bermazhab Syafi'i menjadi hal yang penting untuk dipelajari. Namun, informasi biografi para ulama bermazhab Syafi'i masih berupa media online, buku teks atau kitab yang berbahasa Arab, terpencar-pencar, dan sulit dimengerti. Pada penelitian ini dilakukan pengumpulan data ulama bermazhab Syafi'i dari berbagai sumber dengan suatu pendekatan baru untuk mempelajari biografi ulama bermazhab Syafi'i melalui aplikasi berbasis mobile, dengan metode spatio-temporal. Aplikasi ini menampilkan biografi ulama berdasarkan urutan waktu dan lokasi kelahiran para ulama bermazhab Syafi'i dengan visualisasi peta, sehingga memudahkan pengguna dalam mempelajari biografi ulama. Administrator dapat menambah data ulama melalui website administrator yang terhubung dengan aplikasi secara dinamis. Aplikasi berjalan dengan baik sesuai fungsinya dan pengguna dapat mempelajari biografi para ulama bermazhab Syafi'i dengan visualisasi yang mudah dengan ukuran aplikasi yang ringan dan familiar digunakan oleh pengguna akhir. System Usability Scale (SUS) digunakan sebagai metode usability testing terhadap aplikasi. Skor rata-rata dari 35 responden SUS adalah 77,71 dan termasuk aplikasi yang acceptable dengan kategori "GOOD”.
\end{abstract}

Kata kunci: Ulama bermazhab Syafi'i, Biografi Ulama, Spatio-Temporal, Aplikasi Pembelajaran, Mobile.

\begin{abstract}
Mazhab Syafi'i is a mazhab that is followed by most Muslims in the world. So that, the knowledge of Mazhab Syafi'i, especially the biography and the knowledge sanad of Imam Syafi'i and Syafi'i ulama is important to be learned. However, biographical information of Syafi'i ulama is still in the form of online media, textbooks or books in Arabic, scattered, and difficult to understand. In this study, the data of Syafi'i ulama are collected from various sources with a new approach examines the biographies of Syafi'i ulama through a mobile-based application, using the spatio-temporal method. This application displays biographies of ulama based on the order of time and location of birth of Syafi'i ulama with map visualization, making it easier for users to study biographies of ulama. The administrators of this application can add Syafi'i ulama data through the administrator's website which is dynamically linked to the mobile-based application. The application runs well according to its function and users can learn the biographies of Syafi'i ulama with easy visualization with a light application size and familiar to end users. System Usability Scale (SUS) is used as the method of usability testing of the application. The average SUS value of 35 respondents resulted in an 77.71 and belongs to accepted application in the "GOOD" category.
\end{abstract}

Keywords: Syafi'i Ulama, Biographies of Ulama, Spatio-Temporal, Learning Applications, Mobile.

\section{Pendahuluan}

Mazhab Syafi'i memiliki pengaruh yang luas bagi mayoritas muslim dunia. Mazahab yang didirikan oleh Imam Syafi'i ini adalah mazhab terbanyak pengikutnya sebagai mazhab fikih Sunni [1]. Indonesia, Kamboja, Singapura, Thailand, Vietnam, Filipina, Mesir, dan Iran Somalia bagian Timur adalah negara dengan sebaran mazhab Syafi'i di dalamnya. Bahkan, Brunei Darussalam dan Malaysia 
mengakui mazhab ini sebagai mazhab resmi negara mereka. Dengan jumlah pengikutnya yang besar, para ulama bermazhab Syafi'i itu sendiri dan murid-murid Imam Syafi'i berpengaruh banyak dalam hal persebaran mazhab ini. Maka dari itu, mempelajari dan mengenal sejarah Imam Syafi'i dan muridmurid beliau merupakan salah satu bagian penting dalam ilmu pengetahuan agama Islam. Namun, media pembelajaran biografi para ulama bermazhab Syafi'i yang ada dan digunakan oleh masyarakat saat ini sebagian besar masih berupa buku teks dan media online yang ditulis dengan bahasa Arab dan masih terpencar-pencar menjadi buku-buku yang tebal sehingga sulit dipahami oleh mayoritas masyarakat Indonesia.

Pada zaman dahulu, manusia berguru hingga ke negeri seberang untuk mempelajari ilmu yang mereka butuhkan, utamanya ilmu agama kepada para Imam Mujtahid atau kepada murid-murid dari para imam mujtahid. Para ulama bermazhab Syafi'i atau disebut sebagai ulama Syafi'iyah pun ketika itu sangat gigih dalam menimba ilmu kepada guru-guru mereka, hingga sampai saat ini tersebarlah para ulama Syafi'iyah di seluruh penjuru dunia sehingga berkembanglah dengan pesat Mazhab Syafi'i dan tersebarlah para ulama bermazhab Syafi'i di berbagai negara.

Permasalahan yang dibahas pada penelitian ini yaitu belum ada visualisasi dan platform pembelajaran tentang perjalanan hidup para ulama bermazhab Syafi'i yang terhimpun di dalam suatu wadah dengan mobilitas tinggi dan mudah dimengerti. Pada penelitian ini, penulis mengajukan suatu pendekatan baru untuk media pembelajaran biografi para ulama bermazhab Syafi'i dengan menggunakan fungsi spatio-temporal yang menampilkan biografi para ulama bermazhab Syafi'i dalam suatu tempat dan waktu sekaligus berupa sebuah aplikasi berbasis android mobile. Spatiotemporal berarti yang berhubungan dengan ruang dan waktu. Di dalam spatio-temporal database, digambarkan perubahan geografis dalam jangka waktu tertentu. Database tersebut menyimpan data spasial (berkaitan dengan keruangan) dan data temporal (berkaitan dengan waktu). Data spasial dan temporal ini yang akan dihimpun oleh administrator ke dalam database melalui perantara interface berupa website administrastor. Selanjutnya fungsi spatio-temporal akan disampaikan kepada pengguna melalui visualisasi peta sebagai data spasial yang merupakan kota kelahiran para ulama dan slider tahun yang akan mewakili data temporal tahun kelahiran para ulama Mazhab Syafi'i.

\section{Tinjauan Literatur}

Sirajuddin Abbas [2] membahas tentang kelahiran Imam Syafi'i, perjalanan menuntut ilmu, murid-murid beliau, karya-karya beliau, murid-murid, dan guru-guru beliau. Anny Nailatur \& Ashif Az Zafi [3] membahas biografi singkat Imam Syafi'i, rekam jejak keberadaan Mazhab Syafi'i di Indonesia, dan pengaruhnya terhdap muslim di Indonesia. Teuku Khairul [4] menuliskan tentang sejarah Mazhab Syafi'i dari awal masa terbentuknya sampai dengan tahun $550 \mathrm{H}$ dan menguraikan berkembangnya mazhab ini dari waktu ke waktu, tokoh-tokoh yang berpengaruh, serta faktor yang mempengaruhi perkembangannya. Ahmad Farid [5] membahas mengenai biografi para ulama pilihan, termasuk imam-imam besar, yakni Imam Syafi'i, Imam Bukhari, Imam Nawawi, Ibnu Taimiyah, Ibnu Katsir, dan Ibnu Hajar Al-Asqlani. Riska Nasrillianti \& Sari Diva R. [6] membahas sejarah peradaban Islam kaitannya dengan para ulama di Nusantara pada abad 16 hingga 17. Abd. Rahman \& Mualimin Mochammad [7] membahas jasa para ulama bermazhab Syafi'i, salah satunya Imam Ar-Rafi'i dalam memurnikan mazhab Syafi'i yang sedang berkembang pada saat itu.

\section{Metode Penelitian}

Aplikasi pembelajaran biografi para ulama bermazhab Syafi'i yang dikembangkan merupakan aplikasi berbasis android mobile dan digunakan oleh pengguna akhir (masyarakat umum). Aplikasi mobile menjadi client yang akan meminta response dengan format data tertentu terhadap server yang berupa website administrator.

Metode pengembangan aplikasi dijelaskan oleh desain sistem secara high level view dari client dan server, yang ditunjukkan oleh Gambar 1. 


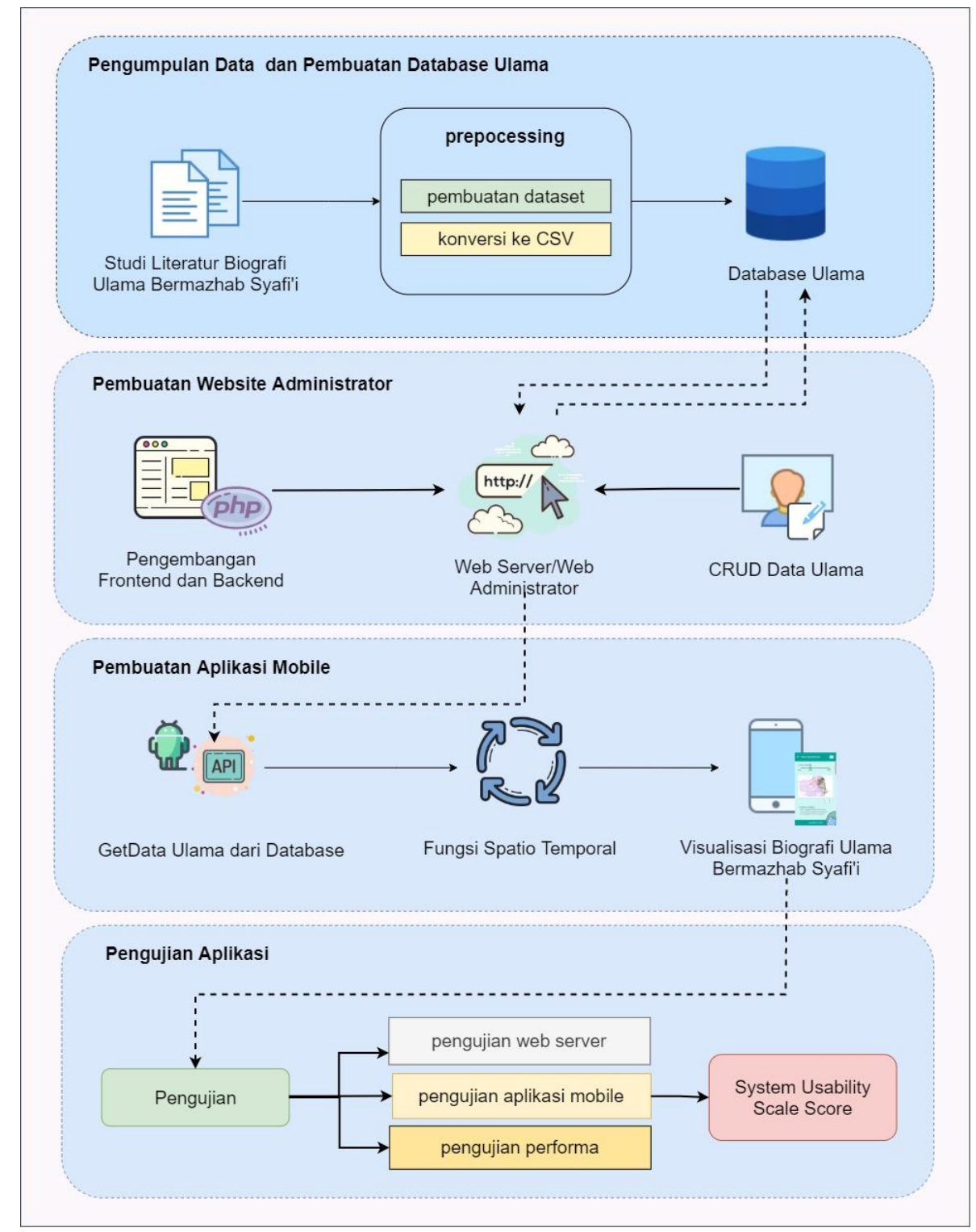

Gambar 1. Desain Sistem Aplikasi

\section{Pengumpulan Data dan Pembuatan Database Ulama}

Pada tahapan pengumpulan data dan Pembuatan Database Ulama, terdapat tiga proses penting yakni studi literatur perjalanan hidup para ulama bermazhab Syafi'i, preprocessing data ulama, serta proses import dataset tersebut ke dalam database. Proses pengumpulan data dan pembuatan database ulama meliputi:

1. Studi Literatur Biografi Ulama Bermazhab Syafi'i. Studi literatur atau studi pustaka yang atau pengumpulan dataset yang dalam proses penelitian ini bertujuan untuk mendapatkan sumber informasi akurat dan sebanyak-banyaknya mengenai biografi para ulama bermazhab Syafi'i dari seluruh dunia. Hal ini dilakukan untuk mengenal lebih jauh objek penelitian [8][9]. Studi literasi dari sumber-sumber akurat yang ada, yaitu buku-buku teks biografi para ulama bermazhab Syafi'i, serta pencarian secara online melalui berbagai website yang memiliki referensi akurat adalah teknik yang dilakukan selama melakukan pengumpulan data. Data biografi para ulama bermazhab Syafi'i yang dikumpulkan utamanya berupa nama ulama, tahun kelahiran, tempat kelahiran, karya-karya tulis atau karangan kitab, tahun wafat, tempat wafat, dan perjalanan hidup beliau. Dikarenakan banyaknya sumber yang memiliki konten yang mirip, pencarian sumber yang terpencar-pencar dan sebagian besar berbahasa Arab, penulis merangkum sebagian sumber yang berhasil penulis dapatkan dokumentasinya sebagaimana yang terdapat pada Tabel 1 . 


\begin{tabular}{ll}
\hline No. & Nama Sumber \\
\hline 1. & Sejarah \& Keagungan Madzhab Syafi'I [2] \\
\hline 2. & Jejak Eksistensi Mazhab Syafi'i di Indonesia [3] \\
\hline 3. & Sejarah Perkembangan Mazhab Syaf'i dari Generasi Salaf hingga Khalaf [4] \\
\hline 4. & 60 Biografi Ulama Salaf [5] \\
\hline
\end{tabular}

Tabel 1. Sumber Literatur

2. Preprocessing data ulama. Setelah melakukan tahapan yang pertama yakni studi literatur, berikutnya adalah preprocessing yang terdiri dari dua sub tahapan, yaitu dataset ulama dan konversi ke bentuk file CSV. Hasil yang didapat dari studi literatur biografi yang berupa nama ulama, tahun kelahiran, tempat kelahiran, karya-karya (kitab karangan), tahun wafat, tempat wafat, dan perjalanan hidup ulama bermazhab Syafi'i dihimpun terlebih dahulu ke dalam format CSV (Comma Seperated Value). Data tersebut yang akan dibawa ke proses selanjutnya. Dengan menggunakan format CSV, data yang saat pengumpulan jumlahnya ratusan dapat digenerate ke database dengan lebih mudah.

3. Import Dataset ke Database. Hal pertama yang perlu dilakukan sebelum melakukan import dataset para ulama ke database adalah melakukan perancangan database yang nantinya akan digunakan sebagai media penyimpanan atau data store dari proses CRUD dataset para ulama oleh administrator melalui perantara website admin. Berikutnya adalah melakukan import dataset tersebut dari format CSV dengan menyesuaikan nama kolom yang ada sesuai dengan field di database.

Pada tahapan ini dihasilkan sebuah sistem database ulama yang menyimpan sejumlah data ulama yang dibutuhkan pada proses berikutnya. Database menyimpan data dari 100 ulama bermazhab Syafi'i.

\section{Pembuatan Website Administrator}

Website administrator dibuat untuk membantu dan menyediakan interface bagi administrator atau pengelola aplikasi kelak dalam melakukan proses administrasi atau perbaruan data para ulama bermazhab Syafi'i untuk data yang ditampilkan di aplikasi, sehingga tidak perlu membuka database secara langsung.

1. Pengembangan Frontend dan Backend. Frontend merupakan bagian antarmuka aplikasi yang akan ditampilkan langsung kepada pengguna, sedangkan backend adalah bagian dari aplikasi yang tidak ditampakkan secara langsung kepada pengguna, yang mengandung fungsi-fungsi tertentu, termasuk fungsi CRUD yang akan digunakan oleh administrator selama mengelola aplikasi [10]. Dalam penelitian ini, pengembangan frontend website administrator dilakukan menggunakan bantuan framework CSS yaitu bootstrap, yang dikenal mudah dan menjadikan website yang dibangun menjadi responsive ketika dijalankan. Sedangkan backend website administrator menggunakan bantuan framework Laravel, yang merupakan framework berbasis MVC (Model View Controller) yang memudahkan developer membangun fungsi-fungsi yang diperlukan oleh website yang dibangun menggunakan bahasa pemrograman PHP.

2. CRUD Data Ulama. CRUD merupakan hal yang penting dalam pengembangan sebuah aplikasi yang berkaitan dengan data dan backend aplikasi [11]. Proses CRUD data ulama bermazhab Syafi'i sehubungan dengan dibangunnya web administrator. Setelah fungsi CRUD dapat berjalan dengan baik, administrator tidak perlu membongkar aplikasi lagi dan data yang ada akan dapat mengalir ke pengguna sebagaimana mestinya. Data para ulama bermazhab Syafi'i yang jumlahnya banyak bahkan ratusan disimpan di dalam database dan untuk melakukan perubahan terhadap data tersebut telah dibantu website administrator sebagai perantaranya. Setiap kali melakukan perubahan data, fungsi PHP akan menghubungkannya juga dan akan melakukan perubahan terhadap data, sehingga data yang ada akan selalu sinkron.

3. Web Server/ Web Administrator adalah hasil atau output dari tahapan pembuatan website administrator. Web Server akan menjadi perantara antara administrator dengan sistem database sehingga data para ulama yang diubah atau ditambahkan dapat sinkron pula di database dan di aplikasi. 


\section{Pembuatan Aplikasi Mobile}

1. GetData Ulama atau Mengambil Data Ulama dari Database: Administrator melakukan proses CRUD data terhadap database dengan perantara web administrator. Selanjutnya data yang sudah disimpan ke dalam database akan ditampilkan juga di aplikasi mobile, sehingga memerlukan web API sebagai penghubung antara database dengan aplikasi mobile. Jika response API telah didapat, maka data dapat ditampilkan. Kemudian visualisasi berupa peta menggunakan Google Maps API, sehingga pengguna akan menerima output berupa data ulama yang diinginkan dan peta kelahiran ulama berdasarkan waktu dan tempat yang dipilih.

2. Fungsi Spatio Temporal. Fungsi spasial (keruangan) akan menghubungkan fungsi spasial yang diwakili oleh peta kelahiran ulama (sebagai representasi dari salah satu bagian biografi ulama) dengan fungsi temporal yang diwakili oleh urutan tahun kelahiran para ulama bermazhab Syafi'i [12]. Fungsi spatio-temporal terhadap peristiwa kelahiran ulama merupakan parameter untuk memunculkan biografi ulama yang merujuk pada tahun dan tempat kelahiran yang dimaksud oleh pengguna. Pengguna dapat memilih lokasi pada peta, kemudian aplikasi akan menampilkan biografi para ulama bermazhab Syafi'i dan tahun kelahirannya. Fungsi temporal (waktu) memungkinkan pengguna memilih tahun yang telah terurut dengan cara menggeser komponen seek bar yang disediakan aplikasi. Angka tahun yang dipilih kemudian akan dihubungkan dengan database, lalu akan diambil data biografi ulama bermazhab Syafi'i dari kolom biografi di database sesuai dengan pilihan tahun tersebut.

3. Visualisasi Biografi Ulama Bermazhab Syafi'i. Sebagai bentuk visualisasi pembelajaran biografi ulama bermazhab Syafi'i, dibangun aplikasi mobile yang akan menampilkan halaman berisi daftar ulama, peta kelahiran para ulama, dan biografi ulama bermazhab Syafi'i. Fungsi spatio temporal akan memudahkan pengguna untuk memahami riwayat hidup para ulama bermazhab Syafi'i dengan adanya seek bar yang mewakili temporal (waktu) kelahiran para ulama yang dapat digeser dan akan memperlihatkan peta sebagai fungsi spasialnya serta secara bersamaan akan menampilkan biografi para ulama yang memiliki tahun kelahiran yang sesuai dengan tahun yang tertera pada seek bar.

Pada tahapan ini dihasilkan sebuah aplikasi mobile bernama UlamaMaps yang menampilkan visualisasi biografi ulama bermazhab Syafi'i dengan memanfaatkan fungsi spatio-temporal.

\section{Pengujian Aplikasi}

Pengujian meliputi pengujian web server, pengujian performa, dan pengujian aplikasi mobile. Pengujian web server dan performa aplikasi dilakukan oleh developer, sedangkan pengujian aplikasi mobile dilakukan oleh pengguna akhir berupa pengujian usability oleh pengguna akhir.

Metode yang dipakai dalam melakukan pengujian usability aplikasi mobile dalam penelitian ini adalah System Usability Scale (SUS). SUS merupakan metode pengujian usability yang populer oleh John Brooke. Metode ini disebut sebagai usability scale yang populer, efektif, andal, efektif, dan murah [13][14]. Pengujian dilakukan untuk mengetahui skor rata-rata unsur usability dari aplikasi dan mengukur pengalaman pengguna yang baik dan mengadopsi navigasi yang mudah bagi pengguna ketika menjalankan aplikasi.

Setelah melakukan usability testing, pengguna akan diberikan kuesioner SUS berupa 10 pertanyaan mengenai usability dari sistem yang dibangun. Pertanyaan-pertanyaan yang ada di dalam kuesioner SUS untuk aplikasi mobile yang dikembangkan dalam penelitian ini ditunjukkan pada Tabel 2. STS atau "Sangat Tidak Setuju", TS atau"Tidak Setuju", RG atau "Ragu-ragu", S atau "Setuju", dan SS atau "Sangat Setuju" yang masing-masing secara berturut-turut bernilai 1, 2, 3, 4, dan 5 . 


\begin{tabular}{|c|c|c|c|c|c|c|}
\hline No. & Pertanyaan & STS & TS & RG & ST & SS \\
\hline 1. & $\begin{array}{l}\text { Saya pikir saya akan menggunakan aplikasi ini } \\
\text { lagi. }\end{array}$ & & & & & \\
\hline 2. & Saya rasa aplikasi ini rumit untuk digunakan. & & & & & \\
\hline 3. & Saya rasa aplikasi ini mudah digunakan. & & & & & \\
\hline 4. & $\begin{array}{l}\text { Saya memerlukan bantuan orang lain atau teknisi } \\
\text { ketika menggunakan aplikasi ini. }\end{array}$ & & & & & \\
\hline 5. & $\begin{array}{l}\text { Saya rasa fitur dari aplikasi ini berjalan } \\
\text { sebagaimana semestinya. }\end{array}$ & & & & & \\
\hline 6. & $\begin{array}{l}\text { Saya rasa terdapat banyak hal yang tidak konsisten } \\
\text { atau tidak serasi dari aplikasi ini. }\end{array}$ & & & & & \\
\hline 7. & $\begin{array}{l}\text { Saya rasa orang lain akan mengerti cara } \\
\text { menggunakan aplikasi ini dengan cepat. }\end{array}$ & & & & & \\
\hline 8. & Saya rasa aplikasi ini membingungkan. & & & & & \\
\hline 9. & $\begin{array}{l}\text { Saya rasa tidak ada hambatan dalam menggunakan } \\
\text { aplikasi ini. }\end{array}$ & & & & & \\
\hline 10. & $\begin{array}{l}\text { Saya membutuhkan pembiasaan diri terlebih } \\
\text { dahulu sebelum menggunakan aplikasi ini. }\end{array}$ & & & & & \\
\hline
\end{tabular}

Tabel 2. Tabel Kuesioner SUS

\section{Cara Menghitung Skor SUS}

Jawaban dari responden untuk kuesioner SUS yang terdiri dari 10 pertanyaan akan dikalkulasi sebagai berikut:

1. Pertanyaan dengan nomor ganjil, bagi masing-masing pertanyaan skornya didapat dari skor responden yang minus 1 .

2. Pertanyaan dengan nomor genap, skor akhirnya adalah nilai 5 minus skor dari pertanyaan yang dijawab responden.

3. Bagi setiap responden mendapatkan skor dari jumlah total skor dari masing-masing pertanyaan dikalikan dengan 2,5.

Selanjutnya, hasil SUS untuk setiap responden dicari nilai rata-ratanya dengan cara menjumlah skor keseluruhan dan dibagi total responden. Berikut adalah formula untuk menghitung skor rata-rata SUS, yang ditunjukkan oleh persamaan (1):

$\bar{x}=\frac{\sum x}{n}$

di mana:

$\overline{\mathrm{x}}=$ skor rata-rata SUS

$\sum \mathrm{x}=$ jumlah skor SUS

$\mathrm{n}=$ jumlah responden

Setelah dilakukan perhitungan nilai skor rata-rata SUS, maka akan didapatkan hasil pengujian aplikasi dan aplikasi atau sistem yang dibangun akan dikategorikan ke dalam Best Imaginable, Excellent, Good, OK, Poor, atau Worst Imaginable. Gambar 2 menunjukkan kategori skor SUS. 


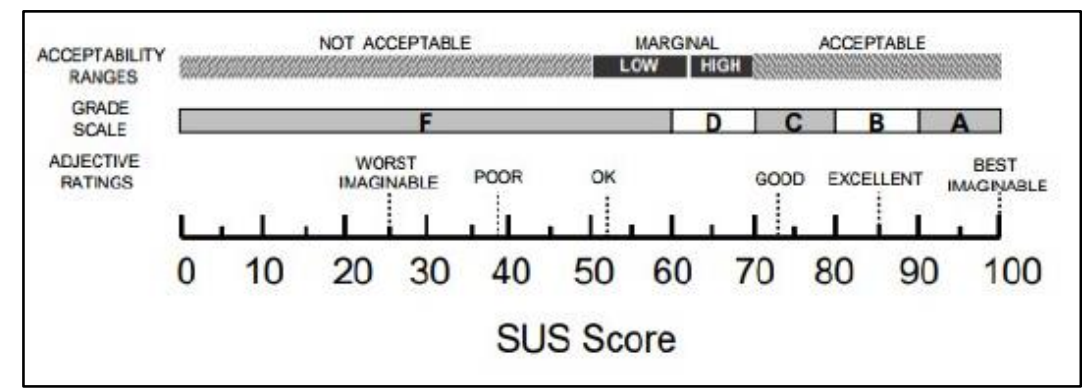

Sumber: https://www.edisusilo.com/cara-menggunakan-system-usability-scale/

\section{Gambar 2. Kategori Skor SUS}

Dari kebanyakan penelitian yang ada, skor rata-rata SUS adalah sebesar 68. Maka sistem yang dibangun termasuk di atas rata-rata jika skor rata-rata SUS yang didapat lebih dari 68. Sedangkan jika nilai yang didapat kurang dari 68 , maka diperlukan perbaikan usability dari sistem yang dibangun.

\section{Hasil dan Pembahasan}

Hasil dari penelitian ini berupa aplikasi android mobile yang digunakan oleh pengguna akhir dan website administrator yang digunakan untuk pengelolaan data ulama atau sebagai web server. Dalam hal ini, aplikasi mobile diberi nama UlamaMaps.

\section{Karakteristik Data}

Dalam pengembangan aplikasi mobile, diimplementasikan kerangka bisnis lean canvas. Lean Canvas merupakan salah satu metode bussines planning yang berupa sebuah halaman. Metode ini dibuat oleh Ash Maurya dan merupakan adaptasi dari Business Model Canvas yang dikembangkan oleh Alexander Osterwalder. Lean Canvas yang digunakan untuk membantu memetakan poin-poin penting dalam bisnis sehingga didapatkan ide yang jelas dan sederhana [15].

\begin{tabular}{|c|c|c|c|c|}
\hline PROBLEM & SOLUTION & $\begin{array}{l}\text { UNIQUE VALUE } \\
\text { PROPOSIMON }\end{array}$ & $\begin{array}{l}\text { UNFAIR } \\
\text { ADVANTAGE }\end{array}$ & $\begin{array}{l}\text { CUSTOMER } \\
\text { SEGMENTS }\end{array}$ \\
\hline $\begin{array}{l}\text { Belum ada visualisasi } \\
\text { dan media } \\
\text { pembelajaran tentang } \\
\text { perjalanan hidup para } \\
\text { ulama bermazhab } \\
\text { Syafi'i yang terhimpun } \\
\text { di dalam suatu } \\
\text { platform dengan } \\
\text { mobilitas tinggi dan } \\
\text { mudah dimengerti. }\end{array}$ & $\begin{array}{l}\text { Aplikasi Spatio- } \\
\text { Temporal } \\
\text { Pembelajaran } \\
\text { Biografi Para Ulama } \\
\text { Bermazhab Syafi'i } \\
\text { berbasis Mobile. }\end{array}$ & $\begin{array}{l}\text { Memudahkan user } \\
\text { dalam mencari } \\
\text { informasi kelahiran } \\
\text { dan biografi Ulama } \\
\text { Mazhab Syafi'i } \\
\text { dengan satu } \\
\text { platform saja yang } \\
\text { mudah diakses. }\end{array}$ & $\begin{array}{l}\text { Custom map pada } \\
\text { aplikasi, user dapat } \\
\text { turut berinteraksi. } \\
\text { Aplikasi GIS tentang } \\
\text { lokasi kelahiran ulama } \\
\text { bermazhab Syafi'i } \\
\text { yang belum pernah } \\
\text { ada sebelumnya. }\end{array}$ & $\begin{array}{l}\text { Masyarakat Umum } \\
\text { (13-60 tahun) }\end{array}$ \\
\hline \multirow{2}{*}{$\begin{array}{l}\text { Sulitnya mendapat } \\
\text { ensiklopedia biografi } \\
\text { para ulama Mazhab } \\
\text { Syafi'i berbahasa } \\
\text { Indonesia. }\end{array}$} & KEY METAICS & High-Level Concept & CHANNELS & \multirow{3}{*}{$\begin{array}{l}\text { Masyarakat umum } \\
\text { yang sedang } \\
\text { mempelajari } \\
\text { biografi para } \\
\text { ulama. }\end{array}$} \\
\hline & $\begin{array}{l}\text { - Buka aplikasi } \\
\text { - Lihat peta dan } \\
\text { biografi ulama Mazhab }\end{array}$ & $\begin{array}{l}\text { Wikipedia dengan } \\
\text { custom map pada } \\
\text { aplikasi mobile. }\end{array}$ & $\begin{array}{l}\text { Kerja sama dengan } \\
\text { pemuka agama. } \\
\text { Promosi Media sosial } \\
\end{array}$ & \\
\hline $\begin{array}{l}\text { Informasi biografi } \\
\text { ulama terpencar- } \\
\text { pencar. }\end{array}$ & Syafi'i & & $\begin{array}{l}\text { Sosialisasi ke } \\
\text { customer }\end{array}$ & \\
\hline \multicolumn{2}{|l|}{ COST STRUCTURE } & \multicolumn{2}{|c|}{ REVENUE STREAMS } & \\
\hline \multicolumn{2}{|c|}{ Biaya Pengembangan aplikasi } & \multicolumn{2}{|c|}{ Subscribe dari customer } & \\
\hline
\end{tabular}

Gambar 2. Lean Canvas Ulama Maps

Menurut lean canvas yang telah penulis susun, pengujian dan penilaian aplikasi mobile UlamaMaps dilakukan oleh masyarakat umum berusia 13-60 tahun sebagai pengguna akhir, seperti yang dapat ditunjukkan pada bagian customer segments pada Gambar 2.

\section{Pengujian Web Server}

Uji coba terhadap website administrator sebagai web server aplikasi UlamaMaps dilakukan oleh administrator setelah terlebih dahulu melakukan login melalui halaman https://ulamamaps.com. Menu yang disediakan oleh website administrator UlamaMaps terdiri dari Dashboard, Daftar Ulama, Biografi Ulama, dan Administrator, yang ditunjukkan pada bagian sidebar di sisi kiri setiap halaman. Di halaman Daftar Ulama, administrator dapat melihat data dari setiap ulama. Administrator juga 
dapat menghapus dan mengedit data dari masing-masing ulama, serta menambah daftar baru, yang meliputi nama asli ulama, nama populer, tahun kelahiran hijriyah dan masehi, tahun wafat hijriyah dan masehi, lokasi kelahiran, kitab/karya ulama, dan biografi ulama. Figur 4 menunjukkan halaman Daftar Ulama website administrator.

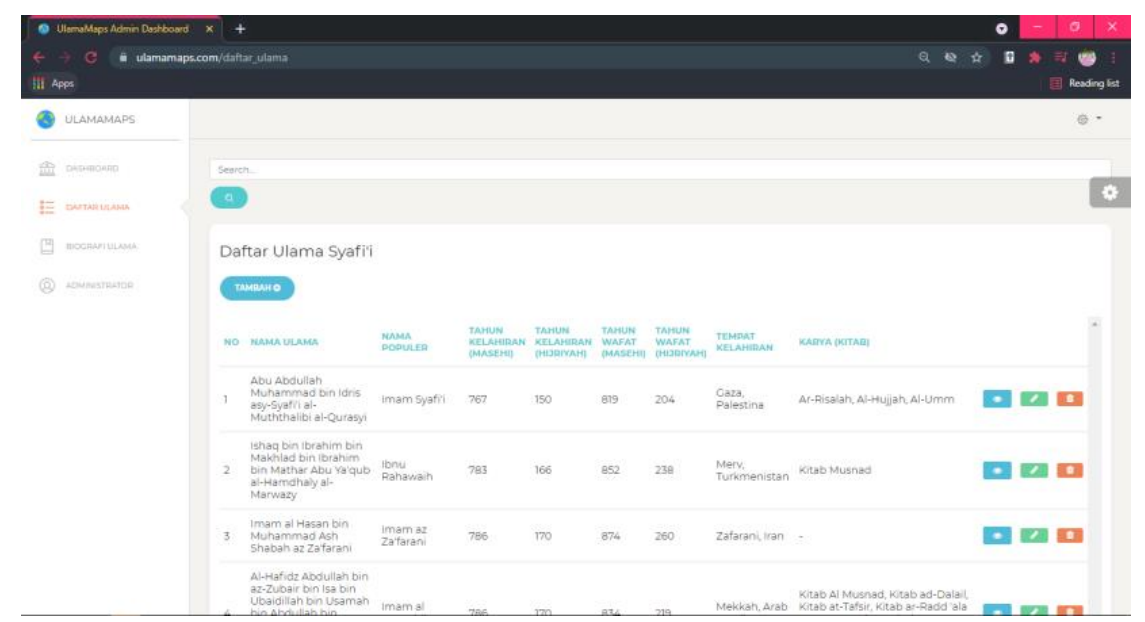

Gambar 3. Halaman Daftar Ulama Website Administrator

Di halaman Daftar Ulama, ketika administrator menekan button tambah ulama, maka akan diarahkan menuju halaman form tambah data ulama, seperti yang tampak pada Gambar 4.

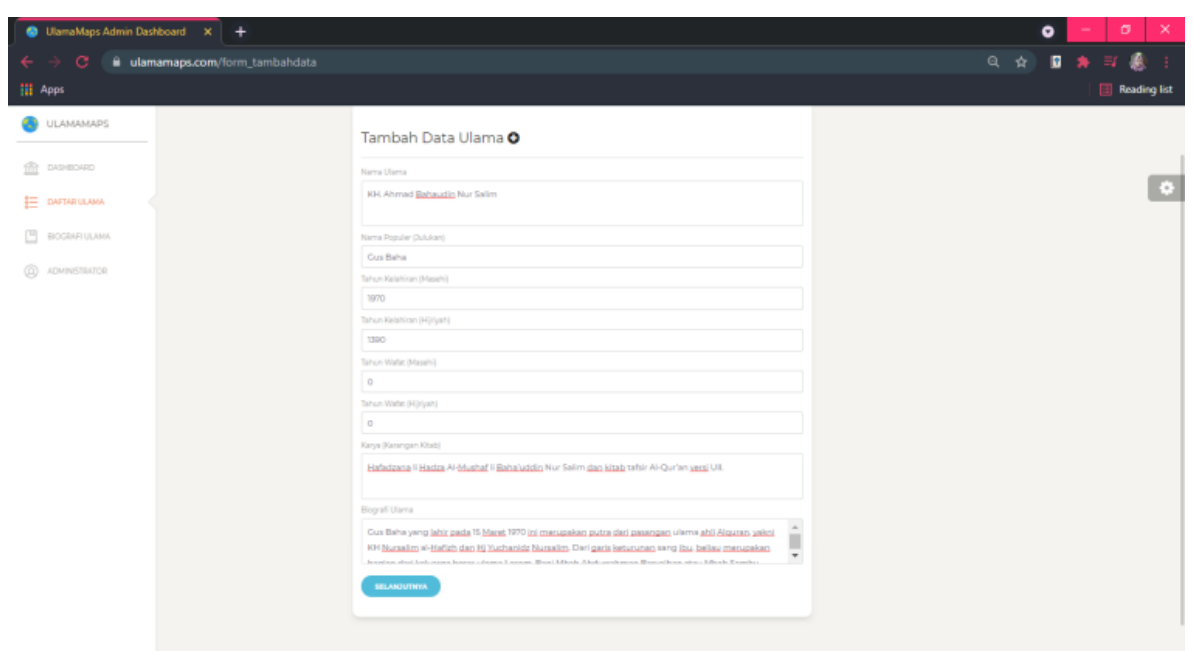

\section{Gambar 4. Form Tambah Data Ulama}

Setelah administrator mengisi form tambah data ulama dengan lengkap, kemudian menekan tombol selanjutnya, sistem akan menuju ke halaman penambahan lokasi kelahiran ulama. Halaman ini ditunjukkan oleh Gambar 5. 


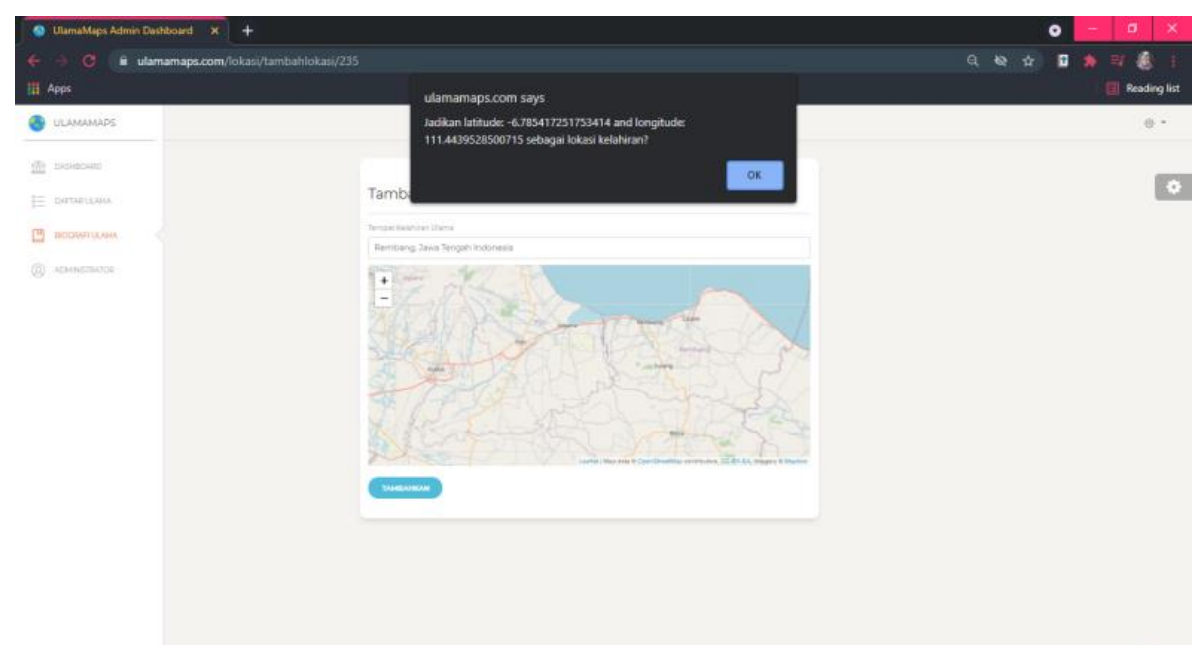

\section{Gambar 5. Halaman Penambahan Lokasi Kelahiran Ulama}

Pengujian operasi delete juga dilakukan terhadap data ulama. Ketika administrator menekan button delete, maka akan muncul pop-up atau pesan untuk menanyakan apakah administrator benarbenar akan menghapus data tersebut atau tidak, seperti yang ditunjukkan oleh Gambar 6. Jika ya, maka barulah data ulama yang dimaksud akan dihapus dari database.

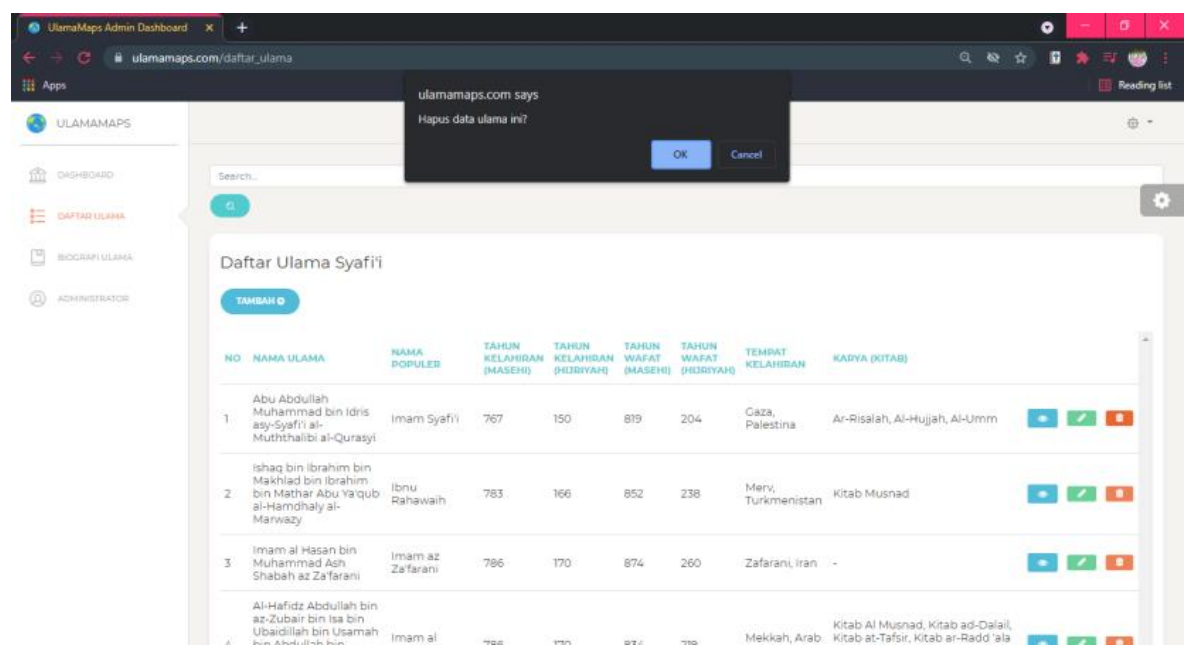

\section{Gambar 6. Contoh Operasi Delete Data Ulama}

Gambar 7 menunjukkan response API yang berhasil ditangkap dan dikembalikan oleh server ke client. Dari hasil pengujian API Web Service, respon berhasil dengan status "OK" dengan waktu pemrosesan total $1151 \mathrm{~ms}$.

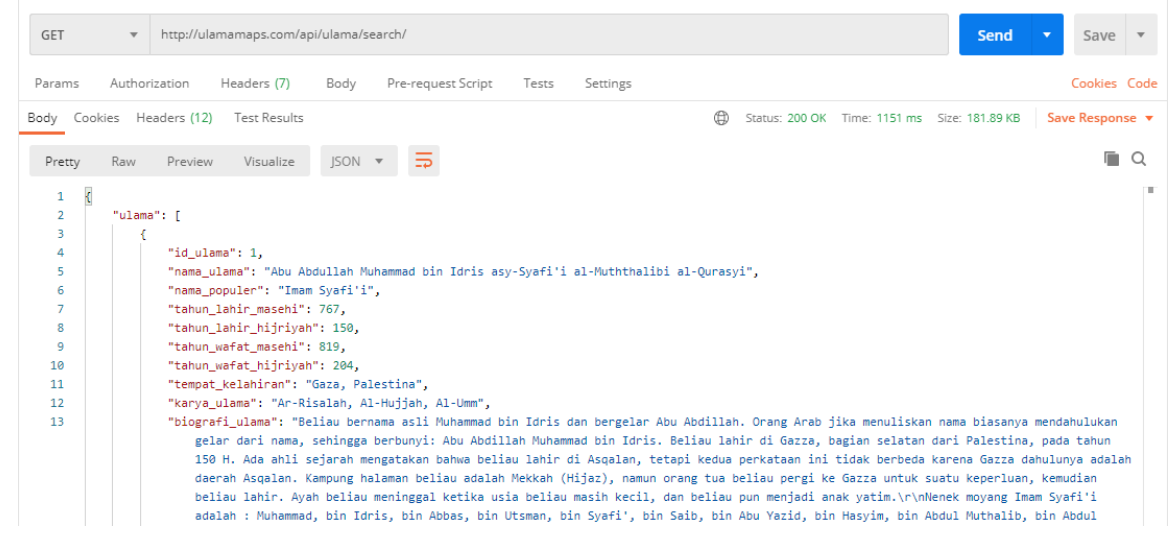

Gambar 7. Pengujian API Web Service 


\section{Pengujian Aplikasi Mobile}

Setelah melakukan instalasi aplikasi, pengguna akan masuk ke halaman utama yang berisi tiga menu, yaitu Daftar Ulama, Peta Kelahiran, dan Biografi Imam Syafi'i. Halaman utama aplikasi UlamaMaps. Gambar 8 menunjukkan fitur pencarian ulama berdasarkan nama populer ulama. Fitur ini dapat ditemukan di halaman Daftar Ulama.

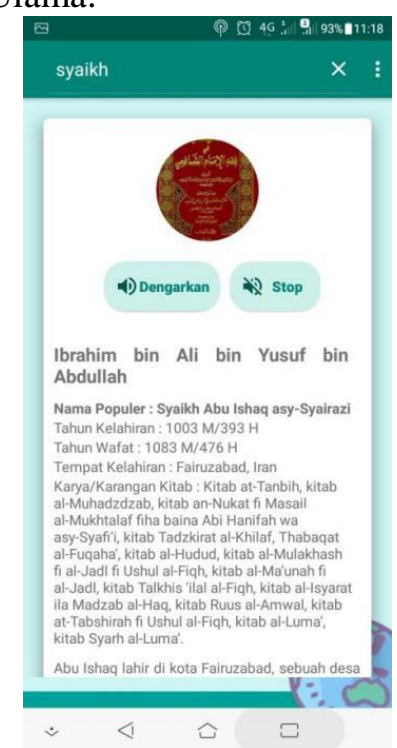

\section{Gambar 8. Fitur Pencarian Ulama berdasarkan Nama Populer}

Halaman aplikasi yang menjadi inti adalah halaman Peta Kelahiran Ulama, seperti yang ditunjukkan oleh Gambar 9. Pada halaman ini ditampilkan peta dunia dengan marker tempat kelahiran ulama sesuai dengan tahun kelahiran yang ingin diketahui oleh pengguna serta daftar ulama yang bersangkutan. Default tampilan pada halaman ini sebelum pengguna menggeser seek bar tahun ke tahun lainnya adalah $150 \mathrm{H}$, yakni kelahiran Imam Syafi'i, yang menjadi pendiri Mazhab Syafi'i.

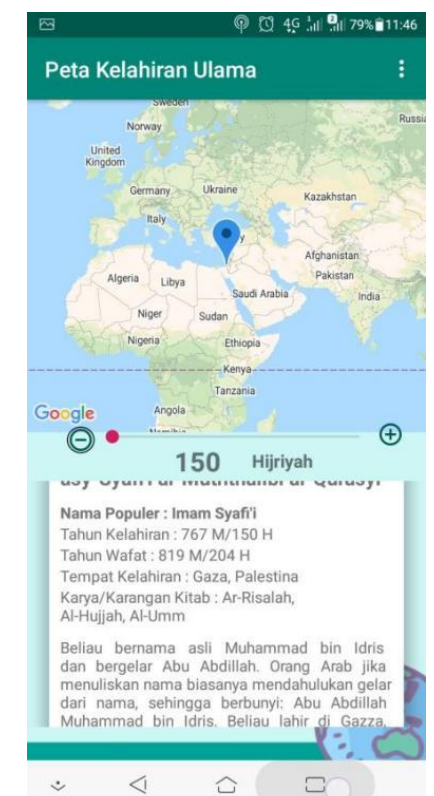

\section{Gambar 9. Halaman Peta Kelahiran Ulama}

Berikutnya, Gambar 10 menunjukkan pengujian terhadap fitur utama aplikasi UlamaMaps, yaitu spatio-temporal yang menampilkan informasi ruang dan waktu secara bersamaan. Fungsi spatiotemporal dalam aplikasi ini merupakan gabungan dari fungsi spasial yang diwakili oleh peta (sistem informasi geografis lokasi kelahiran para ulama) dan fungsi temporal yang diwakili oleh tahun 
kelahiran para ulama. Pengguna dapat memilih tahun kelahiran ulama menggunakan fitur seekbar tahun yang dapat digeser, atau tombol tambah dan kurang. Kemudian akan ditampilkan perubahan pada peta dunia di atas seek bar, di mana data yang diambil menyesuaikan tahun kelahiran ulama yang dipilih pengguna. Peta akan menunjukkan lokasi kelahiran ulama yang memiliki tahun yang sesuai pilihan pengguna dengan penanda berupa marker. Selain tampilan peta kelahiran, akan ditampilkan pula biografi dari ulama yang sesuai dengan query.

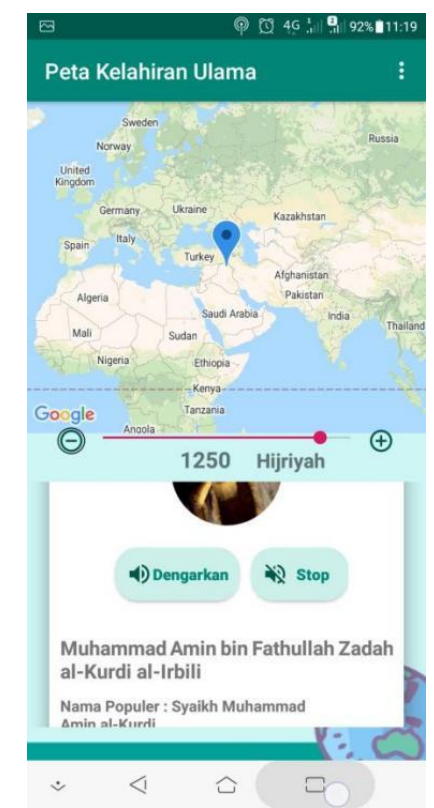

Gambar 10. Fitur Spatio-Temporal UlamaMaps

\section{Pengujian Performa}

Aplikasi mobile UlamaMaps dapat berjalan di smartphone android versi 8.0 dan versi yang lebih tinggi. Tangkapan layar pada Gambar 11 menunjukkan ukuran aplikasi setelah dipasang di smartphone. Aplikasi UlamaMaps termasuk aplikasi mobile yang berjalan tanpa membutuhkan banyak ruang penyimpanan di smartphone. Ruang penyimpanan internal yang dibutuhkan sebesar 17,29 MB dengan penggunaan data internet sebesar 0,98 MB yang digunakan untuk meload data dari server secara online.

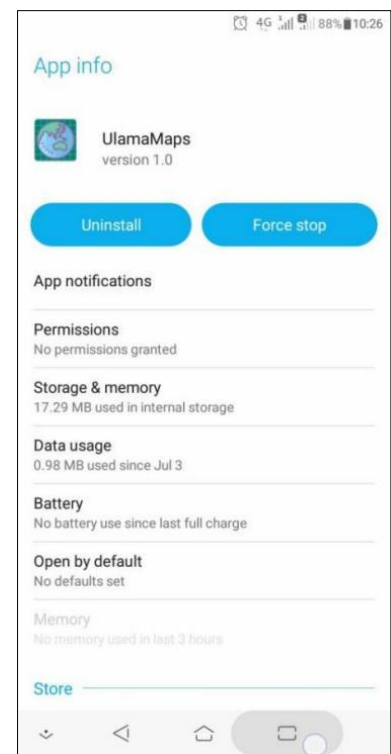

Gambar 11. Informasi Aplikasi UlamaMaps 


\section{Hasil Penilaian Responden}

Pengujian fitur dan usability aplikasi UlamaMaps dilakukan oleh responden sebagai pengguna akhir aplikasi menggunakan smartphone dengan versi Android yang berbeda-beda. Terdapat 35 responden yang menguji coba dan menilai aplikasi. Tabel 3 menunjukkan hasil perhitungan skor SUS aplikasi UlamaMaps.

\begin{tabular}{|c|c|c|c|c|c|c|c|c|c|c|c|c|}
\hline $\mathbf{R}$ & Q1 & Q2 & Q3 & Q4 & Q5 & Q6 & Q7 & Q8 & Q9 & Q10 & $\Sigma$ & $\mathbf{N}$ \\
\hline $\mathrm{R} 1$ & 4 & 3 & 4 & 3 & 3 & 3 & 4 & 4 & 4 & 3 & 35 & 87,5 \\
\hline R2 & 4 & 3 & 3 & 4 & 3 & 3 & 4 & 4 & 3 & 2 & 33 & 82,5 \\
\hline R3 & 1 & 3 & 2 & 3 & 3 & 3 & 3 & 3 & 3 & 3 & 27 & 67,5 \\
\hline $\mathrm{R} 4$ & 3 & 2 & 2 & 3 & 3 & 2 & 2 & 3 & 1 & 1 & 22 & 55 \\
\hline R5 & 3 & 3 & 4 & 2 & 4 & 3 & 2 & 3 & 3 & 1 & 28 & 70 \\
\hline R6 & 4 & 4 & 4 & 4 & 4 & 4 & 4 & 4 & 4 & 4 & 40 & 100 \\
\hline R7 & 4 & 3 & 3 & 4 & 2 & 3 & 3 & 3 & 3 & 3 & 31 & 77,5 \\
\hline $\mathrm{R} 8$ & 4 & 0 & 4 & 0 & 4 & 0 & 4 & 0 & 4 & 0 & 20 & 50 \\
\hline R9 & 2 & 4 & 3 & 4 & 3 & 3 & 3 & 4 & 3 & 3 & 32 & 80 \\
\hline $\mathrm{R} 10$ & 3 & 1 & 4 & 4 & 3 & 2 & 3 & 4 & 3 & 2 & 29 & 72,5 \\
\hline R11 & 4 & 4 & 4 & 2 & 4 & 4 & 3 & 4 & 1 & 0 & 30 & 75 \\
\hline R12 & 4 & 3 & 3 & 3 & 3 & 3 & 3 & 3 & 3 & 3 & 31 & 77,5 \\
\hline R13 & 4 & 2 & 3 & 3 & 3 & 2 & 4 & 3 & 1 & 3 & 28 & 70 \\
\hline R14 & 3 & 4 & 4 & 4 & 4 & 3 & 3 & 4 & 4 & 2 & 35 & 87,5 \\
\hline $\mathrm{R} 15$ & 4 & 3 & 4 & 3 & 4 & 3 & 4 & 3 & 4 & 4 & 36 & 90 \\
\hline R16 & 4 & 3 & 4 & 4 & 3 & 3 & 3 & 4 & 4 & 3 & 35 & 87,5 \\
\hline R17 & 4 & 2 & 3 & 1 & 2 & 2 & 3 & 3 & 1 & 1 & 22 & 55 \\
\hline R18 & 4 & 2 & 2 & 4 & 3 & 2 & 3 & 3 & 2 & 0 & 25 & 62,5 \\
\hline R19 & 3 & 4 & 4 & 4 & 4 & 3 & 4 & 4 & 4 & 4 & 38 & 95 \\
\hline $\mathrm{R} 20$ & 3 & 3 & 3 & 4 & 3 & 3 & 3 & 3 & 3 & 3 & 31 & 77,5 \\
\hline R21 & 3 & 3 & 3 & 4 & 2 & 3 & 3 & 3 & 3 & 3 & 30 & 75 \\
\hline R22 & 4 & 4 & 4 & 4 & 4 & 2 & 4 & 4 & 4 & 2 & 36 & 90 \\
\hline $\mathrm{R} 23$ & 4 & 4 & 4 & 4 & 4 & 4 & 4 & 4 & 4 & 4 & 40 & 100 \\
\hline R24 & 3 & 3 & 4 & 3 & 4 & 4 & 4 & 4 & 1 & 4 & 34 & 85 \\
\hline R25 & 3 & 3 & 3 & 3 & 3 & 3 & 3 & 3 & 3 & 1 & 28 & 70 \\
\hline R26 & 3 & 3 & 3 & 3 & 3 & 3 & 4 & 3 & 3 & 2 & 30 & 75 \\
\hline R27 & 3 & 3 & 3 & 3 & 3 & 3 & 3 & 3 & 3 & 2 & 29 & 72,5 \\
\hline R28 & 4 & 2 & 4 & 3 & 2 & 2 & 3 & 3 & 4 & 3 & 30 & 75 \\
\hline R29 & 4 & 1 & 3 & 3 & 3 & 3 & 3 & 3 & 3 & 1 & 27 & 67,5 \\
\hline R30 & 4 & 4 & 4 & 4 & 3 & 4 & 3 & 4 & 4 & 4 & 38 & 95 \\
\hline R31 & 3 & 3 & 3 & 3 & 3 & 3 & 3 & 3 & 3 & 3 & 30 & 75 \\
\hline R32 & 4 & 4 & 4 & 3 & 4 & 4 & 4 & 4 & 0 & 4 & 35 & 87,5 \\
\hline R33 & 4 & 3 & 4 & 2 & 1 & 3 & 2 & 4 & 2 & 1 & 26 & 65 \\
\hline R34 & 4 & 3 & 3 & 4 & 4 & 1 & 4 & 4 & 2 & 4 & 33 & 82,5 \\
\hline \multirow[t]{2}{*}{ R35 } & 2 & 4 & 4 & 4 & 4 & 1 & 3 & 4 & 4 & 4 & 34 & 85 \\
\hline & & & & & & & & & & $\Sigma \mathbf{X}=$ & & 2720 \\
\hline
\end{tabular}

Tabel 3. Hasil Perhitungan Kuesioner SUS UlamaMaps

Setelah dilakukan perhitungan skor SUS, didapatkan nilai rata-rata SUS dari seluruh responden. Skor yang didapat kemudian akan dicocokkan dan dimasukkan ke dalam kategori yang ada [8].

$$
\begin{aligned}
& \bar{x}=\frac{2720}{35} \\
& \bar{x}=77,71
\end{aligned}
$$


Dari perhitungan SUS di atas, nilai skor rata-rata SUS dari aplikasi UlamaMaps dengan menggunakan 35 responden adalah 77,71. Berdasarkan pengkategorian usability, dapat disimpulkan bahwa aplikasi UlamaMaps termasuk ke dalam kategori "GOOD" dengan nilai skor rata-rata yang di atas rata-rata.

\section{Kesimpulan}

Penelitian ini mencoba menyelesaikan permasalahan belum adanya visualisasi dan media pembelajaran tentang perjalanan hidup para ulama bermazhab Syafi'i yang terhimpun di dalam suatu platform dengan mobilitas tinggi dan mudah dimengerti. Sehingga untuk menyelesaikan permasalahan yang diangkat, maka diajukanlah sebuah pendekatan baru untuk media pembelajaran biografi para ulama bermazhab Syafi'i dengan menggunakan fungsi spatio-temporal yang menampilkan biografi para ulama Mazhab Syafi'i dalam suatu tempat dan waktu sekaligus, berupa sebuah aplikasi berbasis mobile. Aplikasi mobile yang dibangun bernama UlamaMaps, yang dapat berjalan dengan baik di smartphone versi 8.0 dan versi yang lebih baru. Aplikasi ini memiliki tiga menu utama, yaitu Daftar Ulama Bermazhab Syafi'i, Peta Kelahiran Ulama, dan Biografi Imam Syafi'i. Visualisasi dan pembelajaran biografi atau perjalanan hidup para ulama ditampilkan oleh sistem kepada pengguna akhir dengan interface dari halaman Daftar Ulama, serta fitur utama berupa spatio-temporal yang dapat diakses oleh pengguna dengan mudah di halaman Peta Kelahiran Ulama. Pada halaman ini pengguna mengakses fitur spasial berupa peta lokasi kelahiran para ulama dan fitur temporal berupa tahun kelahiran para ulama, sehingga pengguna dapat mempelajari biografi para ulama bermazhab Syafi'i dengan mobilitas tinggi dan visualisasi yang mudah dipahami. Berdasarakan pengujian yang dilakukan dengan metode SUS (System Usability Scale) oleh 35 responden, hasil perhitungan nilai rata-rata SUS untuk aplikasi UlamaMaps adalah 77,71 dan termasuk ke kategori "GOOD”. Oleh karena itu, aplikasi UlamaMaps termasuk ke dalam aplikasi yang dapat diterima oleh pengguna (acceptable) dan dapat digunakan sebagai media pembelajaran biografi para ulama bermazhab Syafi'i.

\section{Referensi}

[1] Alamar, "Imam Syafi'i , Madzhab dan Metodologinya - STIS Al-Manar Jakarta." https://stisalmanar.ac.id/2020/09/09/imam-syafii-madzhab-dan-metodologinya/ (accessed Jul. 16, 2021).

[2] S. Abbas, Sejarah \& Keagungan Madhzab Syafi'i. 2010.

[3] A. N. Rohmah and A. A. Zafi, "Jejak Eksistensi Mazhab Syafi `i di Indonesia," J. Tamaddun J. Sej. dan Kebud. Islam, vol. 8, no. 1, 2020, doi: 10.24235/tamaddun.v8i1.6325.

[4] T. K. Fazli, Sejarah Perkembangan Mazhab Syafi ’i dari Generasi Salaf hingga Khalaf. 2020.

[5] A. Farid, 60 Biografi Ulama Salaf. 2006.

[6] R. Nasrillianti and S. D. Riantiza, "Sejarah Peradaban Islam Ulama-Ulama Nusantara Abad 16-17," no. 11750425184, 2019.

[7] A. R. Bin Rahuni and M. Mochammad Sahid, "Imam Ar-Rafi'i dan Peranannya dalam Perkembangan Mazhab Syafi'i,' J. Al-Shafi'i, vol. 9, no. 2019, pp. 19-37, 2020.

[8] S. Awwaabiin, "Studi Literatur: Pengertian, Ciri-Ciri, dan Teknik Pengumpulan Datanya." https://penerbitdeepublish.com/studi-literatur (accessed Jul. 16, 2021).

[9] S. Setiawan, "Studi Kepustakaan adalah: Tujuan, Sumber, Metode dan Jenis." https://www.gurupendidikan.co.id/studi-kepustakaan/ (accessed Sep. 16, 2021).

[10] A. R. Putri, "Apa Itu Front-End dan Back-End di Dunia Teknologi? | kumparan.com." https://kumparan.com/kumparantech/apa-itu-front-end-dan-back-end-di-dunia-teknologi1qxiD60BCjk (accessed Jul. 16, 2021).

[11] A. S. Oktriwina, "CRUD: Definisi, Fungsi, dan Cara Mengaplikasikannya - Glints Blog." https://glints.com/id/lowongan/crud-adalah/\#.YUHW07gzbDd (accessed Jul. 16, 2021).

[12] A. Fariza, J. Akhmad, N. Hasim, and M. Fikriyah, "Aplikasi Spatio-Temporal Peristiwa Bencana Letusan Gunung Berapi Di Indonesia Pada Piranti Bergerak,” vol. XI, 2016.

[13] E. Susilo, "Cara Menggunakan System Usability Scale (SUS) Pada Evaluasi Usability." https://www.edisusilo.com/cara-menggunakan-system-usability-scale/ (accessed Jul. 16, 2021). 
[14] I. Aprilia, P. I. Nugroho, and R. Ferdiana, "Pengujian Usability Website Menggunakan System Usability Scale," J. IPTEKKOM J. Ilmu Pengetah. Teknol. Inf., vol. 17, no. 1, p. 31, 2015, doi: 10.33164/iptekkom.17.1.2015.31-38.

[15] Gie, "Lean Canvas: Pengertian, Sejarah, Fungsi, Contoh dan Komponennya." https://accurate.id/marketing-manajemen/lean-canvas/ (accessed Jul. 16, 2021). 